\title{
Behavioral Responses of the Endemic Shrimp Halocaridina rubra (Malacostraca: Atyidae) to an Introduced Fish, Gambusia affinis (Actinopterygii: Poeciliidae) and Implications for the Trophic Structure of Hawaiian Anchialine Ponds ${ }^{1}$
}

\author{
Krista A. Capps, ${ }^{2}$ Caroline B. Turner, ${ }^{2}$ Michael T. Booth,$^{2}$ Danica L. Lombardozzi, ${ }^{2}$ \\ Scott H. McArt, ${ }^{4}$ David Chai, ${ }^{3}$ and Nelson G. Hairston $7 r .{ }^{2,5}$
}

\begin{abstract}
In the Hawaiian Islands, intentionally introduced exotic fishes have been linked to changes in native biodiversity and community composition. In 1905, the mosquito fish Gambusia affinis was introduced to control mosquitoes. Subsequently, G. affinis spread throughout the Islands and into coastal anchialine ponds. Previous studies suggest that presence of invasive fishes in anchialine ponds may eliminate native species, including the endemic shrimp Halocaridina rubra. We examined effects of $G$. affinis on $H$. rubra populations in anchialine ponds on the Kona-Kohala coast of the island of Hawai' $i$. In the presence of G. affinis, H. rubra exhibited a diel activity pattern that was not seen in fishless ponds. Shrimp in ponds with fish were active only at night. This pattern was evident in anchialine ponds and in laboratory experiments. In laboratory predation experiments, G. affinis preferentially consumed smaller $H$. rubra, and in the field the $H$. rubra collected from invaded sites were larger than those from fishless ponds. Analysis of trophic position using stable isotope analyses showed that feeding of $H$. rubra was not significantly distinct from that of snails, assumed to feed at trophic level 2.0 on epilithic algae, but G. affinis was slightly omnivorous, feeding at tropic level 2.2. The mosquito fish diet was apparently composed primarily of algae when the defensive behavior of $H$. rubra made them substantially unavailable as prey. The effect of successful establishment of $G$. affinis on shrimp behavior has the potential to alter abundance of benthic algae and processing and recycling of nutrients in anchialine pond ecosystems.
\end{abstract}

The introduction of nonnative species is one of the greatest threats to biotic diversity and ecosystem functioning throughout the world (Mack et al. 2000, Silliman and Bertness 2004). Invasion events are typically linked to human activities (Rejmanek 1996),

\footnotetext{
${ }^{1}$ Manuscript accepted 1 April 2008.

2 Department of Ecology and Evolutionary Biology, Cornell University, Ithaca, New York 14853.

${ }^{3}$ Four Seasons Resort, 72-100 Ka'ūpūlehu Drive, Kailua-Kona, Hawaici 96740.

${ }^{4}$ Department of Entomology, Cornell University, Ithaca, New York 14853.

${ }^{5}$ Corresponding author (e-mail: ngh1@cornell.edu).
}

Pacific Science (2009), vol. 63, no. 1:27-37

(C) 2009 by University of Hawai'i Press

All rights reserved and the introduction of nonnative species will likely continue due to both intentional and unintentional release by humans and ineffective regulations (Crivelli 1995). Species invasions cause major environmental damage and economic losses amounting to billions of dollars annually in the United States alone (Pimentel et al. 2005); therefore, the consequences of invasion are of substantial interest to scientists and concern to policy-makers and the general public (Vitousek et al. 1997).

Fishes have been intentionally introduced throughout the world for sport, as "ornamental" taxa, and for biological control of insect species (Leyse et al. 2004). The U.S. Geological Survey (2006) has reported that a total of 653 species of fishes have been introduced into aquatic habitats in the United States. Introduced fishes have been linked to declines 
in native invertebrate species, especially in previously fishless water bodies (Englund 1999, Townsend 2003, Leyse et al. 2004, Vitule et al. 2006), and to changes in trophic relationships (Cardona 2006). For example, brown trout (Salmo truta) introductions in New Zealand have caused local fish and invertebrate extinctions and changes in the behavior of native fishes and macroinvertebrates (Townsend 1996).

As with other inland water habitats in the United States, fish introductions have been frequent in coastal Hawaiian anchialine ponds-small brackish-water ecosystems found in areas with porous basins, typically of pumice (Brock and Kam 1997). These ponds are hydrologically linked to both groundwater sources and the ocean. Anchialine ponds, restricted in the United States to the Hawaiian Islands (Brock 1977), support endemic communities of native organisms, including two shrimp species, Halocaridina rubra ('ōpae'ula) and Metabetaeus lohena. Historically, these ponds were important to the coastal fishing culture of native Hawaiians and as aquaculture sites (Santos 2006). Currently, populations of $H$. rubra and other anchialine-pond species are threatened by habitat destruction and the introduction of nonnative predatory fishes and shrimps. Previous research suggests that the presence of invasive fishes may eliminate $H$. rubra from ponds (Bailey-Brock and Brock 1993), but the mechanism for their eradication has been unclear. In addition to being biologically important, the 'opae'ula are culturally significant to native Hawaiians and have become important in the aquarium trade (Santos 2006).

One of the fish invaders most commonly found in anchailine ponds is the western mosquito fish, Gambusia affinis (Brock and Kam 1997, Englund 1999). These fish are diurnal consumers and, although they have been introduced throughout the world to control mosquito populations (Pyke 2005), they are also known to feed on other insects, algae, crustaceans, and small vertebrates (Leyse et al. 2004, Pyke 2005). Introductions of mosquito fish have led to reductions in invertebrate populations, changes in phytoplankton abundance, and changes in aquatic chemistry in other systems (Hurlbert et al. 1972, Hurlbert and Mulla 1981). In 1905, 150 G. affinis were brought to the Hawaiian Islands from Texas to promote mosquito control (Stearns 1983). Subsequently, G. affinis spread throughout the Islands and is now present in many anchialine ponds.

The introduction of G. affinis to Hawaiian anchialine ponds could directly affect native shrimp populations in at least two ways: by eliminating the $H$. rubra through consumption and by modifying $H$. rubra behavior, making them less active during the day when vulnerability to visual predation by the fish is greatest. Other studies have shown that predators can affect their prey through consumption or by instigating changes in prey behavior and life history traits (Flecker 1992, Allan 1995). For example, many zooplankton in lakes migrate vertically during the day to dark bottom waters to avoid predation by visually foraging fishes (Zaret and Suffern 1976), a behavior that is in many cases induced by fish kairomones (Lampert and Loose 1992, De Meester et al. 1998). This modification of behavior may incur costs in terms of lost foraging time in illuminated surface waters where algae are more abundant or in the metabolic cost of swimming (Loose and Dawidowicz 1994).

The direct effects of predator introduction, through the reduction or elimination of prey and the alteration of prey behavior, can impact the trophic dynamics of aquatic ecosystems (Nystrom et al. 2001). Gambusia introductions would be expected to add a trophic link to naturally fishless Hawaiian anchialine ponds that typically lack vertebrate predators of H. rubra (Brock and Kam 1997). In fishless ponds, the food chain should have just two trophic levels (and one trophic link): epilithic algae consumed by 'ōpae'ula. Ponds with Gambusia might then be expected to have three trophic levels (two links): algae consumed by 'ōpae'ula, which are in turn consumed by fish. However, if the 'ōpae'ula were effective at evading predation by altering their behavior, the ominivorous Gambusia would be forced to feed in part or entirely on benthic algae, and food chain length shortened to an intermediate position of between 
one and two trophic links. Here, we report the results of a study of Hawaiian anchialine ponds to determine: (1) if $G$. affinis is capable of preying on $H$. rubra under laboratory conditions; (2) if $H$. rubra persists in anchialine ponds after $G$. affinis introduction, and whether its behavior changes so as to facilitate its persistence; and (3) the actual trophic position of $G$. affinis in ponds to which it has been introduced.

\section{MATERIALS AND METHODS}

\section{Study Sites}

All sampling and collection of organisms were conducted in three anchialine ponds at the Four Seasons Hualālai Resort on the Kona-Kohala coast of the island of Hawai' $i$ (Figure 1). Two ponds, Ho'onanea $\left(270 \mathrm{~m}^{2}\right.$, $50 \mathrm{~cm}$ average depth) and Waiiki $\left(48 \mathrm{~m}^{2}, 25\right.$ $\mathrm{cm}$ average depth), contained large populations of the introduced mosquito fish, Gambusia affinis. Ho'onanea also supported a small population of introduced guppies, Poecilia reticulata, and glass shrimps, Paleomonetes spp. The third pond, Wahi pana $\left(4 \mathrm{~m}^{2}\right.$ with average depth of $14 \mathrm{~cm}$ ), contained no fish or glass shrimps. All of the ponds were situated on lava substrate within $100 \mathrm{~m}$ of the ocean and experienced tidal fluctuations in water depth (though all still contained water at low tide). Measurement of salinity in the ponds made in a previous year indicated that they are slightly less saline than seawater, but no salinity measurements were taken during the study reported here. Situated as they were within the Four Seasons Resort, the ponds were either surrounded by landscaped lawn (Ho'onanea and Waiiki) or located in pumice rubble adjacent to a golf course (Wahi pana).

\section{'Ōpae‘ula Occurrence, Diel Behavior Patterns, and Fish Predation}

We measured the abundance of active $H$. ru$b r a$ in each pond (i.e., out and generally visible resting on, or slowly swimming along the submersed rock surfaces) at midday and about $2 \mathrm{hr}$ after sunset on three sampling dates. Due to differences in pond surface area, sampling methods differed among ponds. Ho'onanea and Waiiki were each sampled using a $30 \mathrm{~cm}$ wide net (straight, flat bottom edge) using 10 sweeps of $20 \mathrm{sec}$ each. Because of its small size, Wahi pana could only be sampled with a small net $(10 \mathrm{~cm}$ bottom edge) using brief (5 sec) sweeps moved along the bottom five times. All sampling was carried out on flat lava substrate containing small crevices and holes. In Wahi pana the lava substrate had numerous sharp protrusions around which the sampling net had to be moved. To standardize for net size and sampling time, we report catch per unit effort (CPUE), defined as the number of $H$. rubra caught per centimeter of net width per minute. This measure, although somewhat qualitative for comparisons of shrimp density among ponds, provided a quantitative estimate of diel changes in shrimp abundance on the substrate surface or in the water column within each pond.

In addition to diel changes in abundance patterns in the ponds, we assessed activity patterns in the laboratory using experimental tanks. Each tank was 19 liters in volume filled partway with 8 liters of water obtained from a fishless pond (i.e., no fish kairomones were present to which the 'oppae'ula might react). Six $H$. rubra were added to four tanks containing a small $\left(\sim 20 \mathrm{~cm}^{3}\right)$ porous lava rock. The rock was added as a potential refuge, typical of the holes and crevices in the natural pond substrate. After a $30 \mathrm{~min}$ equilibration period, the location of each $H$. rubra (under refuge or out in the open) was recorded at $30 \mathrm{sec}$ intervals for $10 \mathrm{~min}$. Three G. affinis were then added to each tank and $H$. rubra location was again recorded every $30 \mathrm{sec}$ for $10 \mathrm{~min}$. This experiment was simultaneously conducted in four tanks containing $H$. rubra from Ho'onanea (fish-invaded) and in four tanks containing H. rubra from Wahi pana (fishless) during both day and night, applying a fully factorial design. Nocturnal observations were accomplished using a red diode light only during the period of counting to minimize light disturbance of the $H$. rubra and $G$. affinis.

To assess the potential impact of sizeselective predation by Gambusia in the field, 


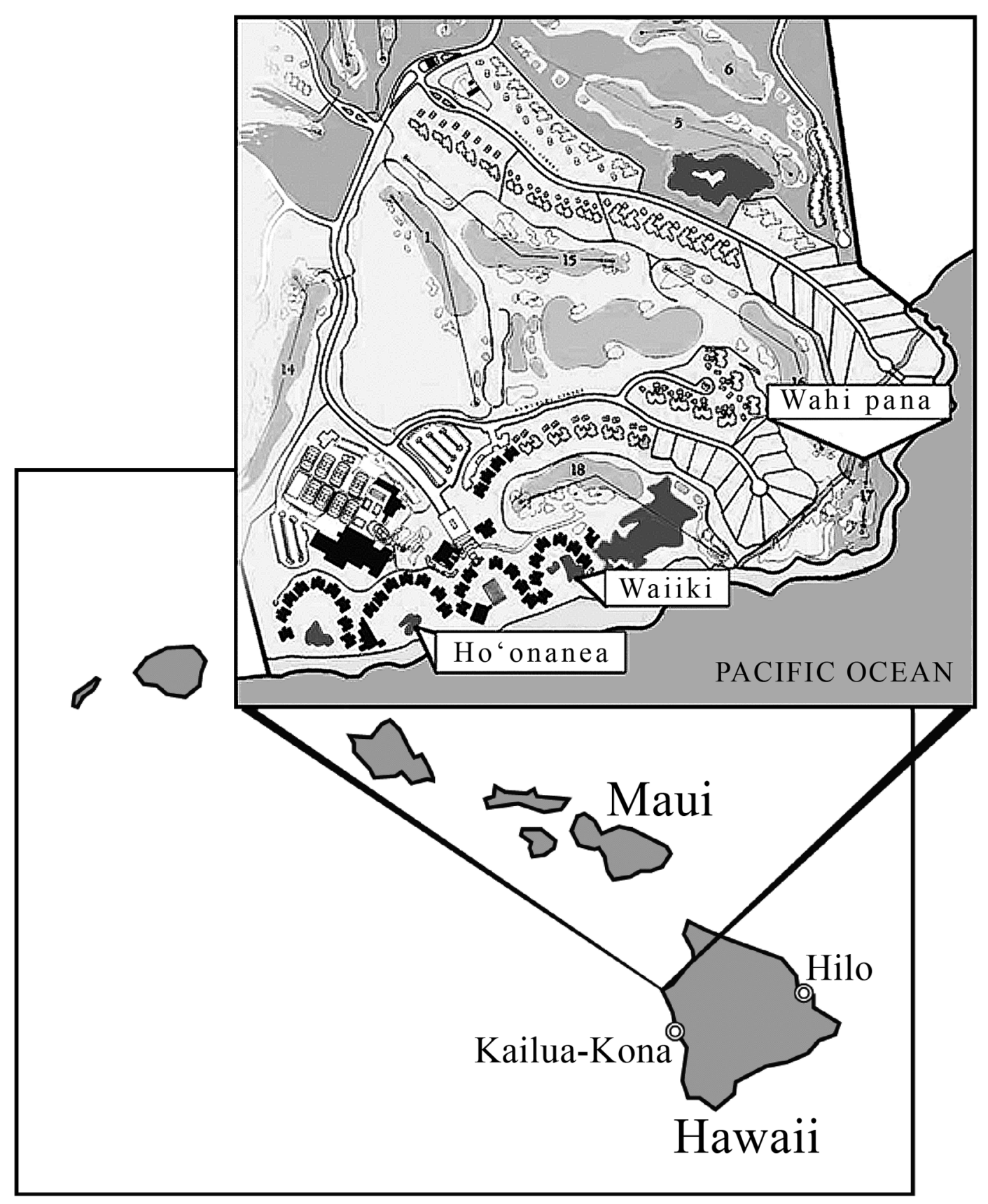

FIGURE 1. Map of study sites. The ponds used in this study included Ho'onanea (fish-invaded), Waiiki (fish-invaded), and Wahi pana (fishless). 
we collected by dip net $(0.5 \mathrm{~cm}$ mesh size $)$ and measured the lengths of $40 \mathrm{H}$. rubra from both Ho'onanea (fish-invaded) and Wahi pana (fishless) ponds. We tested directly for size-selective feeding using laboratory experiments in which three large $(18 \pm 3 \mathrm{~mm}$ long $)$ and three small $(7 \pm 2$ $\mathrm{mm}) H$. rubra were added to each of four experimental tanks each containing three $G$. affinis $(50 \pm 10 \mathrm{~mm})$ and no refuge rock. The tanks were illuminated by natural day and night conditions. The number of $H$. rubra remaining from each size class was recorded at 1, 2, 5, and $24 \mathrm{hr}$ beginning at 0800 hours.

Diel CPUE data and 'ōpae'ula size comparisons were made using Student's $t$-tests. Behavioral and size-selective predation data were normalized by $\log (x+1)$ transformation and analyzed using repeated measures multiple analyses of variance (MANOVAs). All analyses were performed using JMP 5.1.2 statistical software.

\section{Trophic Positions of 'Ōpae'ula and Fish}

The trophic positions of H. rubra and G. affi$n i s$ in the Ho'onanea Pond were determined using $\delta^{15} \mathrm{~N}$ stable isotope analyses (Post 2002), in which the trophic level at which an individual has fed over the course of its life is estimated from analysis of the $\delta^{15} \mathrm{~N}$ of its body tissue. There is typically an enrichment of 3.4\% between the consumer and its diet (Post et al. 2000, Post 2002). Omnivores feeding at more than one trophic level have $\delta^{15} \mathrm{~N}$ contents that represent the weighted average of trophic levels at which they have fed.

We established a baseline for primary consumers (Post 2002) using the $\delta^{15} \mathrm{~N}$ content of benthic snails, Theodoxus sp., which we found crawling on exposed rock surfaces feeding on epiphytic algae and so scored them as having fed all their lives at trophic position 2.0. Snails plus $H$. rubra and $G$. affinis collected from $\mathrm{Ho}^{\prime}$ onanea were placed in ice water for $20 \mathrm{~min}$, frozen overnight, and then dried at $60^{\circ} \mathrm{C}$ for $24 \mathrm{hr}$. Eight samples of $G$. affinis were analyzed, each consisting of homogenized tissue from a single fish. For snails and $H$. rubra, three samples were analyzed, each consisting of homogenized tissue from four individuals. Although these values did not fully represent variation among individuals, this procedure ensured adequate sample sizes for stable isotope analysis and provided greater consistency in defining the general patterns of taxon trophic position.

Tissue from the frozen snails was extracted from the shells under a dissecting stereomicroscope before drying. Dried tissue was flash-frozen with liquid nitrogen and ground for analysis using a mortar and pestle. Three milligrams of dry tissue per sample were analyzed for $\delta^{15} \mathrm{~N}$ using an isotope ratio mass spectrometer (Finnigan MAT Delta Plus). Trophic position was calculated using the standard equation (see Post 2002 for a review):

$$
\text { trophic position }=2+\frac{\left(\delta^{15} N_{\text {sample }}-\delta^{15} N_{\text {snail }}\right)}{3.4}
$$

\section{RESULTS}

\section{'Ōpae'ula Occurrence, Diel Behavior Patterns, and Fish Predation}

'Ōpae'ula were present in both fish-invaded anchialine ponds but exhibited a distinct diel activity pattern not observed in the fishless pond. In ponds with fish, significantly more 'opae'ula were out and active where they could be collected during the night than in daylight, when no 'oppae'ula at all were captured $(t=2.3, \mathrm{df}=5, P=.004$ for Ho'onanea; $t=2.42, \mathrm{df}=5, P=.004$ for Waiiki). The CPUE at night averaged $1.2 \pm 0.5$ and $0.4 \pm 0.2$ (mean CPUE \pm 1 SE) in Ho'onanea and Waiiki, respectively (Figure 2). In contrast, there was no difference in the numbers of $H$. rubra observed and captured during day and night in fishless Wahi pana (CPUE day $4.8 \pm 2.0$, night $2.1 \pm 0.7$; difference not significant: $t=1.27, \mathrm{df}=5, P=$ $.27)$.

The results of the laboratory behavioral experiments were consistent with our field observations. During daylight, a greater fraction of $H$. rubra from the fish-invaded pond was found under the refuge rocks than was the case for individuals from the fishless pond (Figure 3). This was true whether fish were present in the experimental tanks 


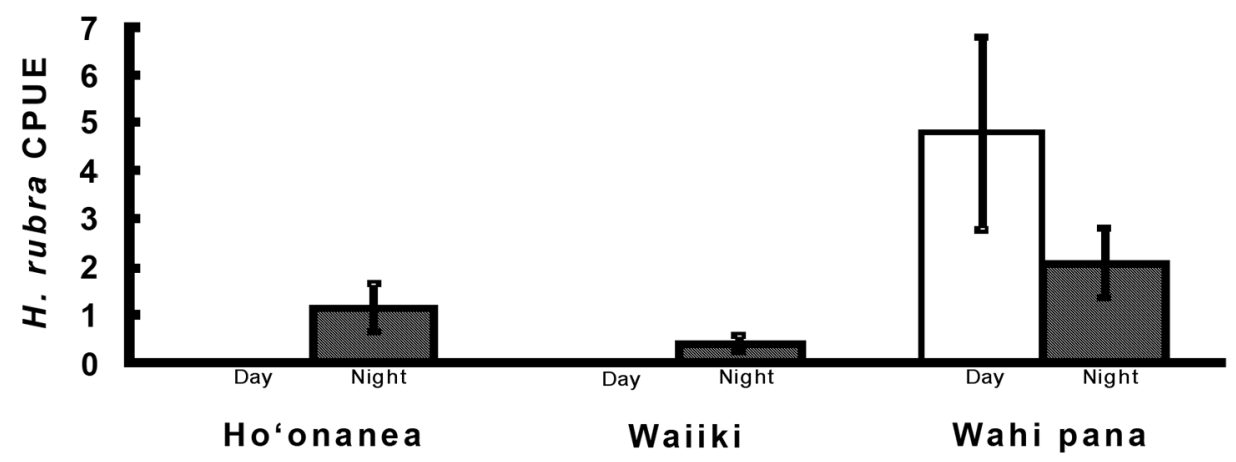

FIGURE 2. Catch per unit effort (CPUE: individuals $\mathrm{cm}^{-1} \mathrm{~min}^{-1}$; mean $\pm 1 \mathrm{SE}$ ) of $H$. rubra during three diel sampling periods at two fish-invaded ponds (Ho'onanea and Waiiki) and one fishless pond (Wahi pana). See Materials and Methods for details on calculation of CPUE.

\section{A. H. rubra from fish-invaded pond}

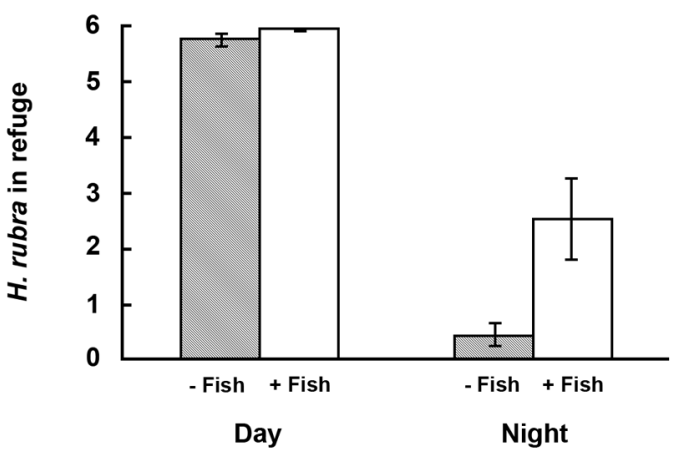

B. $H$. rubra from fishless pond

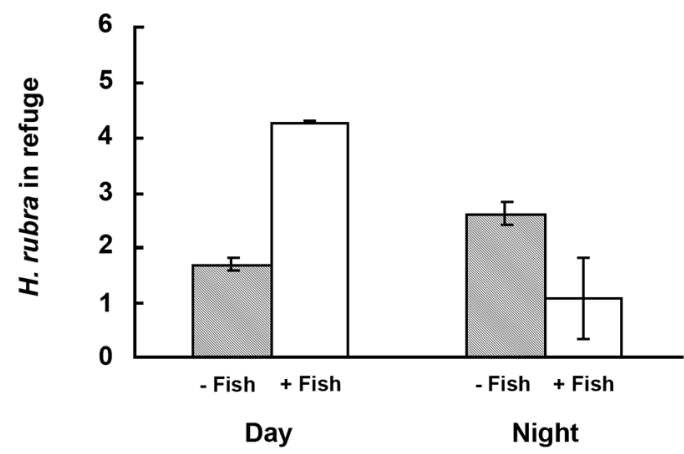

Figure 3. Refuge use by H. rubra from fish-invaded and fishless ponds in tank experiments. Bar height indicates the mean number $( \pm 1 \mathrm{SE}$ ) of $H$. rubra using lava rock refuges during the observation period. $A$, results for $H$. rubra collected from fish-invaded Ho'onanea Pond; $B$, results for H. rubra from fishless Wahi pana pond.
$(F=221.39, \mathrm{df}=6, P<.0001$ for all $)$ or not $(F=8.88, P=.03)$; indeed, the 'oppae'ula from the invaded pond were found under the refuges in more than $95 \%$ of observations. At night, however, there was no difference in the behavior of $H$. rubra from fish-invaded and fishless ponds $(F=1.39, P=.29$ with fish; $F=0.18, P=.68$ fishless). On average, $70 \%$ of the 'opae'ula from both ponds were found in the open, not under the refuge rocks (Figure 3). The H. rubra from fish-invaded ponds were more often under refuge rocks when fish were present than when fish were absent during both night $(F=10.48, P=.02)$ and day $(F=30.68, P<.01)$. However, $H$. rubra from fishless ponds made less use of refuges at night when fish were present than when fish were absent $(F=10.53, P=.02)$. In the absence of fish, $H$. rubra from fishless ponds did not exhibit a change in behavior between day and night $(F=2.62, P=.16)$.

'Ōpae'ula collected from Ho'onanea (fishinvaded) were $57 \%$ larger $(t=10.62, \mathrm{df}=$ $77, P<.0001)$ than those collected from Wahi pana (fishless). In laboratory predation experiments, $G$. affinis preferentially consumed smaller $H$. rubra $(F=9.60, \mathrm{df}=6$, $P=.02)$. In fact, all of the small H. rubra and none of the large $H$. rubra were consumed. Because no refuge rock was present in these experiments (to make feeding by fish possible), the differences in vulnerability to predation can be attributed to size-selective predation. Although we directly observed $G$. affinis consume small 'ōpae'ula, our observa- 


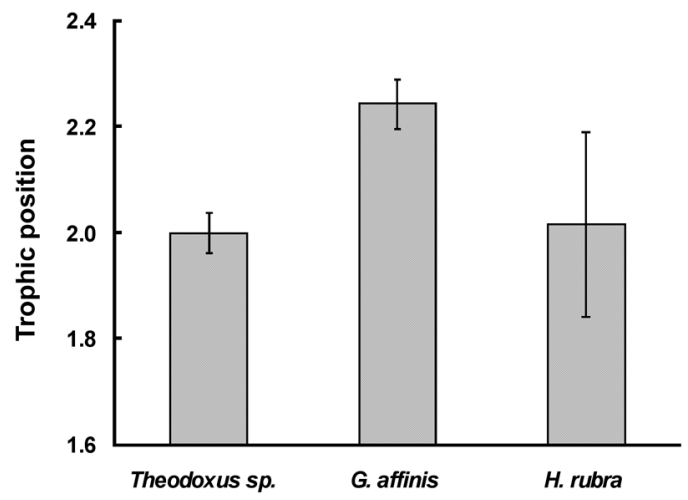

Figure 4. Trophic position (mean $\pm 1 \mathrm{SE}$ ) of Theodoxus sp., G. affinis, and H. rubra in a fish-invaded anchialine pond (Ho'onanea) as estimated from stable isotope data. See Materials and Methods for details on calculation of trophic position.

tions suggested that the large 'ōpae'ula, common in the fish-invaded ponds, were too large for the $G$. affinis to handle and were only very rarely even attacked by the fish.

\section{'Ōpae'ula and Fish Trophic Position}

The trophic positions of the 'oppae'ula, fish, and reference snails did not differ significantly (ANOVA, $F=3.31, \mathrm{df}=11, P=.07$ [Figure 4]). In particular, 'ōpae'ula had a mean $\delta^{15} \mathrm{~N}$ value essentially identical to that of the reference snails and thus a trophic position of 2.0. The trophic position of the shrimp was also not significantly different from that of the fish, although for unknown reasons the variability in 'ōpae'ula $\delta^{15} \mathrm{~N}$ values was substantially larger than that for either the snails or the mosquito fish (Figure 4), which may have impacted the power of the ANOVA to detect interspecific differences. We carried out a separate test for differences in trophic position between the G. affinis and reference snails, because of the lower variance in trophic positions of these taxa compared with the shrimp. Gambusia affinis had a slightly, but significantly, higher mean $\delta^{15} \mathrm{~N}$ value than the snails ( $t$-test, $t=2.94, \mathrm{df}=9$, $P=.02)$, indicating a trophic position of 2.2 (e.g., $80 \%$ algae and $20 \%$ herbivorous invertebrates).
DISCUSSION

The diel behavior of the endemic shrimp $H$. rubra in anchialine ponds along the KonaKohala coast of Hawai'i is significantly impacted by introduced mosquito fish. In ponds where fish have been introduced, the 'oppae'ula exhibited a strong diel activity pattern not seen in the fishless ponds. They were not found on visible rock surfaces or in the water column during the day but were abundant in those locations at night (Figure 2). Laboratory behavior experiments show that the fish are selective predators on smaller individuals in the 'ōpae'ula population and that 'oppae'ula from ponds with fish hide during the day under rocks and are out in the open at night, whether or not fish are present in the water with them (Figure 3). 'Ōpae'ula from a fishless pond did not show any diel activity pattern either in the pond or in the laboratory without fish present. Even in the presence of fish, these 'opae'ula made less use of refuge than those from fishless ponds (Figure 3). Despite the fact that the fish feed on the 'oppae'ula when given an opportunity, the diel behavior of the 'oppae'ula that live in fish-invaded ponds is so effective at avoiding predation that the trophic position of the omnivorous fish is the same as that of the 'opae'ula in habitats where the two species co-occur: both feed almost exclusively at the second trophic level, presumably mainly or entirely on periphytic algae (Figure 4). The observation that there was much greater variability in the trophic position of the shrimp than in either the snails or the fish (Figure 4) may reflect differences in the body sizes of the pooled shrimp, indicating a potential ontogenic diet shift by 'ōpae'ula.

Previous studies have demonstrated that introduced predators can eliminate native species directly through consumption (e.g., Donald et al. 2001, Parker et al. 2001, Roth et al. 2006), and studies of the impact of fish introductions on Hawaiian anchialine ponds have suggested that $H$. rubra was effectively eliminated from these habitats (Brock and Kam 1997). The mosquito fish is a visually foraging predator; therefore, it would not have been surprising to find that it caused the local extinction of highly visible bright 
red 'ōpae'ula. Yet, in other systems, crustacean zooplankton can adapt to the presence of fish through altered diel behavior, where they migrate during the day to dark hypolimnetic bottom waters and back to the surface waters at night to feed (De Meester et al. 1998). Zooplankton living in lakes that have contained fish for many years have been found to exhibit more extensive diel vertical migration than do those in lakes where fish have only recently been introduced (Gliwicz 1986).

Several studies have found that aquatic prey can evolve life histories and morphologies that reduce vulnerability in the presence of introduced predators (e.g., Reznick and Endler 1982). For example, Daphnia respond to fish chemical cues in the water by maturing more quickly and at a smaller body size than they do in the absence of fish cues (Castro et al. 2007), and in some shrimp populations size and demographics have been found to change in the presence of increased fish predation (Bass et al. 2001, Goudswaard et al. 2006). Our short-term study was not designed to test the effects of introduced predators on either the life history or morphology of 'oppae'ula; however, it is suggestive that the H. rubra in ponds with fish were of a substantially larger size that was invulnerable to predation by the gape-limited $G$. affinis. It would be interesting to explore the extent to which the behavioral and morphological differences observed between $H$. rubra from fish-invaded and fishless ponds represent phenotypically plastic responses to the presence of predators or genetically based adaptation. If the differences represent plasticity, their induction clearly took longer than the $24 \mathrm{hr}$ that we held the 'opae'ula in laboratory conditions. If evolutionary change underlies the differences we observed, it would have to have been extremely rapid: Gambusia affinis had only been present in the fish-introduced ponds (Ho'onanea and Waiiki) for $2 \mathrm{yr}$ at the time of our study. However, evolution at this time scale has been found frequently in other systems where native species have responded to anthropogenic environmental change (Hendry et al. 2007) and is one potential ameliorating response of natural pop- ulations to species introductions (Kinnison and Hairston 2007).

Similar predator-induced shifts in foraging behavior by prey have been documented in many environments where predators have been introduced (e.g., Culp and Scrimgeour 1993, Fraser et al. 2004). For example, Culp and Scrimgeour (1993) determined that, in the presence of fish, mayflies shifted from diurnal to nocturnal foraging. Our results indicate that a similar shift occurred in anchialine pond shrimp populations after mosquito fish introduction. Behavioral responses to predation may also have ecosystem-level consequences: Peckarsky et al. (2002) found that mayflies develop faster and emerge at a smaller size in the presence of chemical cues produced by trout, thereby potentially impacting the biomass and production of the epiphytic algae on which they feed. Such changes may also be seen in anchialine pond environments if nocturnally active $H$. rubra are less effective at foraging.

Mosquito fish did not consume large $(>10$ mm) H. rubra in our study but did consume small $(<10 \mathrm{~mm})$ individuals. Gambusia, like many other small fish, are size-selective feeders, with selected prey size a function of fish size (Bence and Murdoch 1986). The selective feeding on small 'ōpae'ula that we documented is notable because $H$. rubra was significantly larger in ponds where fish were present $(11.6 \pm 1.3 \mathrm{~mm}$ in Ho'onanea) than where fish were absent $(7.4 \pm 2.1 \mathrm{~mm}$ in Wahi pana). These results demonstrate the importance of refugia for $\mathrm{H}$. rubra in invaded systems. Without the shelter provided by the porous pumice substrate, mosquito fish invasion would likely lead to local extinctions of the 'oppae'ula.

Gambusia affinis is an opportunistic omnivore (Leyse et al. 2004), consuming macroinvertebrates and small vertebrates in addition to algae (Pyke 2005). It is interesting that although the mosquito fish we tested were capable of consuming small $H$. rubra, our $\delta^{15} \mathrm{~N}$ data show that, assuming a simple foodchain, the $G$. affinis obtained about $80 \%$ of its diet from algae, with the remaining $20 \%$ coming from herbivores such as 'oppae'ula. Apparently the behavior and body size of the 'ôpae'ula 
are substantially effective in removing them as a significant food source for the fish. The G. affinis then take on a trophic role as herbivores in the pond ecosystems and may, over the course of a day-night activity cycle, become competitors with the 'opae'ula for algal resources in the ponds (Figure 4).

'Ōpae'ula are known to feed actively on periphytic algae in Hawaiian anchialine ponds, an activity that maintains biodiversity in the anchialine pond environment (BaileyBrock and Brock 1993). Removal of H. rubra from anchialine ponds could result in the rapid accumulation of algae (Brock 1987), though algivory by the fish and nocturnal foraging by the 'opae'ula may ameliorate this effect. Fish introductions to anchialine pond ecosystems may alter the processing and cycling of nutrients, the abundance of benthic algae, and the level of primary productivity. The magnitude of these effects and the role of behavioral and morphological adaptation by $H$. rubra must play an important, but currently unquantified, role in these dynamics.

\section{ACKNOWLEDGMENTS}

We thank the Kohala Center, Waimea, Hawaici, for generous financial and logistical support. Staff of the Four Seasons Hualālai Resort were extremely helpful and accommodating during our sampling visits. We also thank C. D. Harvell, J. P. Sparks, J. P. Andras, C. E. Greene, D. M. Vallano, and members of the Cornell Graduate Field Course in Tropical Ecology for providing field assistance and suggestions on the research and manuscript.

\section{Literature Cited}

Allan, J. D. 1995. Stream ecology: Structure and function of running waters. Kluwer Academic Publisher, Boston, Massachusetts.

Bailey-Brock, J. H., and R. E. Brock. 1993. Feeding, reproduction, and sense organs of the Hawaiian anchialine shrimp Halocaridina rubra (Atyidae). Pac. Sci. 47:338355.

Bass, C. S., S. Bhan, G. M. Smith, and J. S.
Weis. 2001. Some factors affecting size distribution and density of grass shrimp (Palaemonetes pugio) populations in two New Jersey estuaries. Hydrobiologia 450:231-241.

Bence, J. R., and W. W. Murdoch. 1986. Prey size selection by the mosquitofish: Relation to optimal diet theory. Ecology 67:324-326.

Brock, R. E. 1977. Occurrence and variety of fishes in mixohaline ponds of the Kona Hawaii coast. Copeia 1977:134-139.

-1987. Status of the anchialine pond system of the Kona-Hawaii coast. Bull. Mar. Sci. 41:633-634.

Brock, R. E., and A. K. H. Kam. 1997. Biological and water quality characterization of anchialine resources in KalokoHonokohau National Historical Park. Cooperative National Park Resources Studies Unit, University of Hawai'i at Mānoa, Honolulu. Univ. Hawai'i Tech. Rep. 112.

Cardona, L. 2006. Trophic cascades uncoupled in a coastal marsh ecosystem. Biol. Invasions 8:835-842.

Castro, B. B., S. Consciencia, and F. Goncalves. 2007. Life history responses of Daphnia longispina to mosquitofish (Gambusia bolbrooki) and pumpkinseed (Lepomis gibbosus) kariomones. Hydrobiologia 594:165-174.

Crivelli, A. J. 1995. Are fish introductions a threat to endemic fresh-water fishes in the northern Mediterranean region. Biol. Conserv. 72:311-319.

Culp, J. M., and G. J. Scrimgeour. 1993. Sizedependent diel foraging periodicity of a mayfly grazer in streams with and without fish. Oikos 68:242-250.

De Meester, L., P. Dawidowicz, E. Van Gool, and C. J. Loose. 1998. Ecology and evolution of predator-induced behavior of zooplankton: Depth selection behavior and diel vertical migration. Pages 160-167 in R. Tollrian and C. D. Harvell, eds. The ecology and evolution of inducible defenses. Princeton University Press, Princeton, New Jersey.

Donald, D. B., R. D. Vinebrooke, R. S. Anderson, J. Syrgiannis, and M. D. Graham. 2001. Recovery of zooplankton assem- 
blages in mountain lakes from the effects of introduced sport fish. Can. J. Fish. Aquat. Sci. 58:1822-1830.

Englund, R. A. 1999. The impacts of introduced poeciliid fish and Odonata on the endemic megalagrion (Odonata) damselflies of Oahu Island, Hawaii. J. Insect Conserv. 3:225-243.

Flecker, A. S. 1992. Fish predation and the evolution of invertebrate drift periodicity: Evidence from neotropical streams. Ecology $73: 438-448$.

Fraser, D. F., J. F. Gilliam, J. T. Akkara, B. W. Albanese, and S. B. Snider. 2004. Night feeding by guppies under predator release: Effects on growth and daytime courtship. Ecology 85:312-319.

Gliwicz, M. Z. 1986. Predation and the evolution of vertical migration in zooplankton. Nature (Lond.) 320:746-748.

Goudswaard, K. P. C., F. Witte, and J. H. Wanink. 2006. The shrimp Caridina nilotica in Lake Victoria (East Africa), before and after the Nile perch increase. Hydrobiologia 563:31-44.

Hendry, A. P., N. P. Patrik, and L. H. Rieseberg. 2007. The speed of ecological speciation. Funct. Ecol. 21:455-464.

Hurlbert, S. H., and M. S. Mulla. 1981. Impacts of mosquitofish (Gambusia affinis) predation on plankton communities. Hydrobiologia 83:125-151.

Hurlbert, S. H., J. Zelder, and D. Fairbanks. 1972. Ecosystem alteration by mosquitofish (Gambusia affinis) predation. Science (Washington, D.C.) 175:639-641.

Kinnison, M. T., and N. G. Hairston. 2007. Eco-evolutionary conservation biology: Contemporary evolution and the dynamics of persistence. Funct. Ecol. 21:444-454.

Lampert, W., and C. J. Loose. 1992. Plankton towers-bridging the gap between laboratory and field experiments. Arch. Hydrobiol. 126:53-66.

Leyse, K. E., S. P. Lawler, and T. Strange. 2004. Effects of an alien fish, Gambusia affinis, on an endemic California fairy shrimp, Linderiella occidentalis: Implications for conservation of diversity in fishless waters. Biol. Conserv. 118:57-65.

Loose, C. J., and P. Dawidowicz. 1994.
Trade-offs in diel vertical migration by zooplankton - the costs of predator avoidance. Ecology 75:2255-2263.

Mack, R. N., D. Simberloff, W. M. Lonsdale, H. Evans, M. Clout, and F. A. Bazzaz. 2000. Biotic invasions: Causes, epidemiology, global consequences, and control. Ecol. Appl. 10:689-710.

Nystrom, P., O. Svensson, B. Lardner, C. Bronmark, and W. Graneli. 2001. The influence of multiple introduced predators on a littoral pond community. Ecology 82:1023-1039.

Parker, B. R., D. W. Schindler, D. B. Donald, and R. S. Anderson. 2001. The effects of stocking and removal of a nonnative salmonid on the plankton of an alpine lake. Ecosystems 4:334-345.

Peckarsky, B. L., A. R. McIntosh, B. W. Taylor, and J. Dahl. 2002. Predator chemicals induce changes in mayfly life history traits: A whole-stream manipulation. Ecology 83:612-618.

Pimentel, D., R. Zuniga, and D. Morrison. 2005. Update on the environmental and economic costs associated with alieninvasive species in the United States. Ecol. Econ. 52:273-288.

Post, D. M. 2002. Using stable isotopes to estimate trophic position: Models, methods, and assumptions. Ecology 83:703-718.

Post, D. M., M. L. Pace, and N. G. Hairston Jr. 2000. Ecosystem size determines foodchain length in lakes. Nature (Lond.) 405:1047-1049.

Pyke, G. H. 2005. A review of the biology of Gambusia affinis and G. bolbrooki. Rev. Fish Biol. Fish. 15:339-365.

Rejmanek, M. 1996. A theory of seed plant invasiveness: The first sketch. Biol. Conserv. 78:171-181.

Reznick, D., and J. A. Endler. 1982. The impact of predation on life history evolution in Trinidadian guppies (Poecilia reticulate). Evolution 36:160-177.

Roth, B. M., C. L. Hein, and M. J. Vander Zanden. 2006. Using bioenergetics and stable isotopes to assess the trophic role of rusty crayfish (Orconectes rusticus) in lake littoral zones. Can. J. Fish. Aquat. Sci. 63:335-344. 
Santos, S. R. 2006. Patterns of genetic connectivity among anchialine habitats: A case study of the endemic Hawaiian shrimp Halocaridina rubra on the island of Hawaii. Mol. Ecol. 15:2699-2718.

Silliman, B. R., and M. D. Bertness. 2004. Shoreline development drives invasion of Phragmites australis and the loss of plant diversity on New England salt marshes. Conserv. Biol. 18:1424-1434.

Stearns, S. C. 1983. A natural experiment in life-history evolution-field data on the introduction of mosquitofish (Gambusia affinis) to Hawaii. Evolution 37:601-617.

Townsend, C. R. 1996. Invasion biology and ecological impacts of brown trout Salmo trutta in New Zealand. Biol. Conserv. $78: 13-22$.

. 2003. Individual, population, community, and ecosystem consequences of a fish invader in New Zealand streams. Conserv. Biol. 17:38-47.

U.S. Geological Survey. 2006. Nonindigenous aquatic species. http://nas.er.usgs .gov/. U.S. Geological Survey, Washington, D.C.

Vitousek, P. M., C. M. Dantonio, L. L. Loope, M. Rejmanek, and R. Westbrooks. 1997. Introduced species: A significant component of human-caused global change. N. Z. J. Ecol. 21:1-16.

Vitule, J. R. S., S. C. Umbria, and J. M. R. Aranha. 2006. Introduction of the African catfish Clarias gariepinus (Burchell, 1822) into southern Brazil. Biol. Invasions 8:677-681.

Zaret, T. M., and J. S. Suffern. 1976. Vertical migration in zooplankton as a predator avoidance mechanism. Limnol. Oceanogr. 21:804-813. 